\title{
Unravelling the Myth: Exploring State and Religion under Aurangzeb
}

\author{
Aniket Tathagata Chettry* \\ Assistant Professor, Department of History, Siliguri College, India
}

Submission: July 26, 2018; Published: August 30, 2018

*Corresponding author: Aniket Tathagata Chettry, Assistant Professor, Department of History, Siliguri College, India, Tel: 8637806065/ 7838058033; Email : aniketc44@gmail.com

\begin{abstract}
Traditional historiography often identifies Aurangzeb as 'communal' or as a 'religious bigot' whose orthodox policies alienated large sections of Hindu community away from Mughal rule weakening the base of the Mughal empire in the subcontinent. This article emphasizes on the need to contextualize most of Aurangzeb's actions before he be labelled as communal or a bigot. This paper attempts to explore the politics behind many of Aurangzeb's most controversial actions like the levying of jizyah or the destruction of temples to show that most of Aurangzeb's policies were a response to the political exigencies encountered by him rather than being fueled by any quest for imposing a rigid Islamic order throughout the Mughal empire [1-3]. This article also focuses on several other aspects of Aurangzeb's reign, often ignored by the traditional historiography which clearly indicates Aurangzeb's willingness to conform to the model of rule laid down by Akbar which was based on a broad idea of tolerance and patronage to all religions.
\end{abstract}

Keywords: Mughal; Aurangzeb; Religion; Politics; State; Political act; Temples; Historiography; Community; Bigot; Tolerance; Patronage; Orthodoxy; Landholdings; Rhetoric

\section{Introduction}

Aurangzeb ascended the Mughal throne in 1658 after having emerged victorious in a bloody succession war against his brothers and having imprisoned his father-the erstwhile Sultan Shahjahan. For the next forty-nine years Aurangzeb ruled the Mughal empire, a period during which the empire reached its territorial zenith extending far south into the rich fertile valleys of the Karnataka region and even penetrating eastwards into the heart of the territories ruled over by the Ahom rulers. By the time Aurangzeb died in 1707, the Mughal empire ruled over a population that was double the size of contemporary Europe, had an army that counted among the largest in Asia and Mughal landholdings reached an all-time high $[4,5]$. However, the legacy of Aurangzeb till date is primarily that of a bigoted ruler whose bigotry was considered responsible for undermining the allembracive social order so painstakingly established by Akbar and maintained by the likes of Jahangir and Shahjahan. Aurangzeb's zeal for Islamic orthodoxy is understood to have inaugurated a period of tyrannical oppression of the Hindu subjects of the Mughal empire; this discontentment of the Hindus expressing itself through a series of 'Hindu' rebellions like those of the Jats, Satnamis, Marathas, Rathores to name a few. While one does not deny the presence of these rebellions during Aurangzeb's reign, what appears to be more problematic is the simplified argument inherent in labeling these actions in terms of a mere religious binary explained by 'righteous Hindus' revolting against an 'evil Muslim' ruler [6].
A look at a few basic questions can problematize this otherwise straight forward proposition around the assessment of Aurangzeb as a ruler: Were those who were rebelling resorting to such means to safeguard the religious rights of 'Hindus' as a group or were there other more political and economic reasons behind these uprisings? Could it be said that all Rajputs or all Marathas sided with the Rathores or with Shivaji when they rose against Aurangzeb? If there were also considerable number of Marathas and Rajputs who fought on the side of Aurangzeb during these very clashes, how does one explain the good Hindu- bad Muslim divide? Was a policy like temple desecration that is often used to indicate Aurangzeb's deep-seated religious orthodoxy [7], really a pervasive policy applied by Aurabgzeb to all temples throughout his empire? If not, on what basis were temples destroyed? Were policies of Aurangzeb like the extremely unpopular idea of levying jizyah motivated by his zeal for restoring the position of Islam in the subcontinent or were there deeper motivations that prompted such acts?

Thus, posing such questions and trying to find their answers is extremely crucial in reaching a more nuanced understanding of Aurangzeb, his piety and his politics [8,9]. This paper would try to investigate some of these questions and through them reassess the complex socio-political challenges that Aurangzeb faced in his rule and the way he responded to these challenges. An evaluation of these challenges and responses is expected to also put into perspective the debate regarding whether 
Aurangzeb was indeed a religious bigot or was there more to his statecraft than a mere love for Islamic orthodoxy.

\section{The Piety and Politics of Aurangzeb}

In the eighth year of his reign Aurangzeb constrained festivities on occasion of Nauroz, the persian new year. Subsequently, from 1668 onwards, Aurangzeb is attributed with having issued a series of decrees which included withdrawal of imperial patronage from certain practices like official history writing and music. Additionally, it is also believed that Aurangzeb ceased appearing for jharokha darshans, and even stopped the practice of tuladan $[10,11]$. In his personal life, Aurangzeb was more pious than his predecessors who abstained from all forms of alcohol and opium, prayed regularly and sewed prayer-caps and copyied the Quran by hand in his free time. All these contributed in creating an aura around Aurangzeb as a puritan and an Islamic bigot who strove to establish a socioreligious order based on the principles of Islamic orthodoxy with no place for anything non-permissible to the Islamic order. However, before accepting such an assessment of Aurangzeb as an orthodox it is important to pay closer attention to each of these actions that are attributed to Aurangzeb.

While it is true that he did try to constraint festivities of Nauroz, it had nothing to do with the un-Islamic character of this festival. Rather, Aurangzeb issued such a command primarily because he viewed such festivals as a threat to public order. Hence, not just Nauroz, Aurangzeb even tried to curb the festivities associated with Diwali, Holi, Muharram and even those associated with the major Muslim festivals of EId-ul-Fitr and Eid-ul-Adha. To a certain extent Aurangeb's fears were not completely unwarranted as festivals in India did have a tendency of becoming law and order issues. Foreign travel accounts are replete with incidents of violence on festivals like Muharram and Holi. Keeping in mind public safety, Aurangzeb issued such orders though it must be kept in mind that there was no general order for banning these festivals and there are several evidences which testify the celebration of festivals like Holi, Diwali and Eid. Similarly, there was no overall ban imposed on music either $[12,13]$. Rather Catherine Butler Brown suggests that the 'ban' if at all was primarily in the form of prohibition of music in the presence of the emperor himself. This was more a matter of personal renunciation and was not forced upon other connoisseurs.

Therefore, one finds several prominent nobles of Aurangzeb actively encouraging and patronizing musicians and singers at this period. Infact, more musical treatises were composed in the period of Aurangzeb than in the period of his predecessors and Brown suggests that Aurangzeb himself encouraged theoretical discourses on music. Regarding literature too, it must be kept in mind that Aurangzeb was too well read to condemn literature or poetry in general [14]. His letters frequently bore references to the likes of Sadi, Hafiz, Rumi and others. As late as 1675, Aurangzeb presided over the compilation of a legal compendium known as Fatwa-i-Alamgiri. He supported a huge imperial library and frequently donated huge sums for the preservation of manuscripts. Thus, it is unlikely such a person would ban literature. What seems more plausible is a withdrawal of imperial patronage to the qasidagos or panegyrists. However, patronage and encouragement of all sorts of poets continued amongst princes and nobles of the court [15].

It is imperative to keep in mind that Aurangzeb legitimized his political claim on grounds of his adherence to orthodox Islam. In one of his letters to his imprisoned father, Aurangzeb presents himself as having taken up the burden of kingship for 'restoring peace and the rule of Islam'. Similarly, Aurangzeb brought about the execution of Dara Shukoh on grounds of his purported heresy. Thus, for Aurangzeb, in the first part of his reign it was essential to demonstrate to the world his commitment to the Islamic strictures to maintain his political authority which relied on his adherence to the precepts of Islam. The various proclamations attributed to Aurangzeb thus needs to be placed within this context as part of his efforts to show that his kingship was strictly in conformity to the Islamic principles he upheld. This does not however mean that the celebration of festivals or the practicing of music or the tradition of literature disappeared from Mughal India. Rather, as discussed above all these cultural forms continued to flourish throughout Mughal India giving the impression that these prohibitions were only a part of his public persona that he maintained but was not enforced upon others.

Statecraft and Aurangzeb: Exploring Aurangzeb's Religious Rhetoric considering his Statecraft

One of Aurangzeb's most debated and controversial policy was his imposition of the jizyah in 1679. Examining the logic behind this action Saqi Mustaid Khan argues that Aurangzeb's desire to uphold the laws of sharia and thereby suppress the infidels forced him to pass an injunction allowing for the imposition of jizyah. Saqi Mustaid Khan was supported by Ali Muhammad Khan and Iswardas who agree with him but also emphasise on the role of the ulema. According to them, the ulema realizing Aurangzeb's zeal for upholding the rules of the Sharia represented to him that the levying of the jizyah on the infidels was compulsory according to the sharia. These arguments emphasize on Aurangzeb's regard for Islamic tenets and his deference to the ulema as the main causes behind the imposition of jizyah. The jizyah was primarily a tax that was levied on the non-Muslim populace.

In Aurangzeb's reign, the money obtained from jizyah was deposited in a separate treasury called the ' khazanah-i-jizyah'. The proceeds from this was to be given as charity to members of the learned class and to theologians. The officials who were charged with the responsibility of looking after this treasury were all staffed from the ulema class. For Aurangzeb who sought a public persona of one who ruled according to the injunctions of the sharia, the imposition of jizyah provided an ideal opportunity to validate such claims. Furthermore, the levying of 
jizyah and keeping the proceeds in the hands of the theological classes has also forced historians to suggest that Aurangzeb had a high regard for the ulema whom he constantly appeased. However, the jizyah issue merits two important questions [16]. Firstly, did Aurangzeb's public acts like the imposition of jizyah imply a close relationship between the emperor and the ulema? Secondly, did Aurangzeb's constant need to portray himself as a ruler whose social order was based on upholding the laws of sharia ensure his violation of the Akbarid social order based on ideas of sulh-i-kul?

In Islamic conception of the state, the ulema, umrah and the sultan were the three pillars of the state. However, Akbar barring the early years of his reign never allowed the members of the ulema to dictate affairs of the state. His aim was to reduce the power of the ulema and the mahzarnama of 1579 is often seen as a landmark step in curbing the ulema. The ulema had a very narrow perception of the state where the state would be guided by the interests of the Islamic community with the non-believers being constantly suppressed. Akbar on the other hand never wanted the state to be confined to the precepts of a religion [17]. For him, justice was the cornerstone of the social organization which could only be achieved by maintaining the balance among diverse interest groups and only then could the society strive towards a state of perfection.

On the other hand, as this paper has already mentioned Aurangzeb's claim to power relied on his adherence to the Islamic principles, so it is but natural to assume that Aurangzeb would give much more prominence to the ulema in matters of governance. The imposition of jizyah and the privileges accorded to the Islamic clerical classes in collection of jizyah can easily be proofs of the deferential attitude that the emperor had towards the ulema. However, such an assumption would be far from the actual reality of Aurangzeb's attitude to the ulema [18]. A cursory glance at Aurangzeb's policies make it very clear that he did not like the interference of the ulema in matters of statecraft. For instance, the ulema was always critical of the assimilation of Hindus to high ranks with the Mughal administration and they were the most vocal opponents of the Mughal policy of entering matrimonial alliances with the Rajputs.

Aurangzeb's ascension did not change this trend of increasing Hindu participation in Mughal administration despite repeated protestations from the ulema class. Under Akbar, Hindus constituted $22.5 \%$ of all Mughal nobles. In the first twenty years of Aurangzeb's rule this remained at a steady $21.6 \%$. Between 1679-1707 Aurangzeb increased Hindu participation at the elite levels of the Mughal state by nearly $50 \%$, with Hindus occupying $31.6 \%$ of the nobility. This 'Hindu' section included large number of Rajputs, Marathas as well as other caste and sectarian groups. Not only were they appointed within the administration, but they were also given high mansabs. Marathas like Kanhoji Deccani and Yashwant Rao enjoyed a mansab of 5000 and 4000 respectively. Later when Shivaji's son Shahu was imprisoned by the Mughals, he was given a mansab of 7000 .
Rajputs from different clans also enjoyed high mansabs. The likes of Jaswant Singh of Marwar and Jai Singh of Amber enjoyed mansabs of 7000 while Raj Singh of Mewar had a rank of 6000 . Even the Iranis despite mainly belonging to Shia sect did well under Aurangzeb. Between 1658-1678, 23 Iranis held the rank of 5000 and above. Though between 1678-1709, their number had come down to 14 Iranis enjoying a rank of 5000 and above, only 6 Turanis held a similar rank in this period. Aurangzeb's attitude to administration becomes evident from his reply to a petition drafted by a Muslim from Bukhara who had entered Mughal service. He had requested the withdrawal of Persians from high positions as they were Shias and not Sunni. To this Aurangzeb's reply was that religion should be kept away from worldly affairs and administration should be vested in men of ability irrespective of their religious affiliations. Thus, this shows that in matters of state craft Aurangzeb did not depart from established Mughal practices and if the views of the ulema were clashing with his views of statecraft, he always gave precedence to the latter over the former.

Similarly, Aurangzeb like his predecessors liked interacting with learned divines of various denominations. He was known for having discourses with the Bairagi saint Mangaldas Maharaj whom he also gave large grants and his visiting of the tombs of famous Sufi saints is also well known. In 1686-87 on way to annexing the Golconda state, Aurangzeb spent a week in the mausoleum of the famous Sufi saint Gesu Daraz. Even in his patronage, Aurangzeb was fairly catholic. Aurangzeb renewed the land grants of several temples at Mathura, Allahabad, Brindavan and elsewhere. In 1687, the emperor gave land to Ramjivan Gosain to build houses for 'pious Brahmins and fakirs'. In 1691, he conferred eight villages and substantial tax-free land to support the Balaji temple. In 1698, he granted lland to a Brahmin named Rang Bhatt in Khandesh. Aurangzeb enacted similar policies towards the Jains as well granting land at Shatrunjaya, Girnar and Mount Abu in the late 1650s. In 1681, he donated land for a Jain monastery to a Jain monk named Lal Vijay. As late as 1703 , he issued orders to stop people from harassing the Jain religious leader Jina Chandra Suri. He also gave lavish gifts to the Sikh gurudwara at Dehradun.

These are only a few examples, but they indicate that despite Aurangzeb's claims of being the protector of Islam and implementing the Sharia in matters of state, as far as functioning of the government is concerned Aurangzeb did not deviate from the established Mughal traditions of governance [19]. He kept relying on an ethnically, linguistically and religiously diverse nobility for the smooth functioning of his administration. People were still given the freedom to practice and preach the religion of their choice. One does not hear of any state-sponsored conversion drives being initiated by Aurangzeb. Occasional cases of conversion did take place, but such converts were mostly small Zamindars or petty state employees who converted expecting preferential treatment after their conversion. Aurangzeb was liberal in matters of providing endowments to religious 
institutions and most religious groups enjoyed the munificence of the emperor. He also frequently interacted with members of other religious beliefs.

The ulema would not have enjoyed many of these measures as these policies would have been contradictory to their narrow Sunni-oriented sharia-based view of the state but the fact that these practices continued till the time of Aurangzeb's death indicate that the ulema were not policy makers and that the emperor rarely sought their advice in state matters. Aurangzeb's relation with the ulema was often shaped by his political requirements. When Aurangzeb's vision of state clashed with the ideas of the clerical class, Aurangzeb did not hesitate in suppressing the interests of the ulema. This is extremely clear from Aurangzeb's decision to conquer Golconda and Bijapur [20]. The theological elements in the emperor's camp were not impressed by the decision as is evident from the refusal of the Shaikh-ul-Islam to give a fatwa to the campaign who felt the decision to wage war against a fellow Muslim ruler is unlawful. However, Aurangzeb was not swayed, and he carried out his campaign despite the opposition of the ulema.

Similarly, when Aurangzeb felt his political interests required appeasing the ulema, he did, as is evident from the imposition of the jizyah. The fact that the jizyah was imposed in 1679- 22 years after Aurangzeb ascended the throne has been pointed by many historians as indicative of the fact that it had to do less with the emperor's desire to upholding the shariah than with political requirements of the period [21-23]. 1679 was the time when Aurangzeb was facing a myriad of problems: the Sikhs had become rebellious in areas around Punjab while the conflict with the Rathore showed no signs of abating and had only intensified in the years leading upto the levying of the jizyah. Siimilarly, the region of Deccan posed a challenge to Aurangzeb as well with the Marathas under Shivaji constantly harassing Mughal forces and encroaching upon Mughal territories. To make matters worse, Aurangzeb's policy of shoring up the Bijapur or Golconda state against the Marathas had also failed with these states more willing to ally with Shivaji than with the expansionist Mughal state. In such a situation, to mobilize Muslim support behind him Aurangzeb felt the need for reverting to a rhetoric of an orthodox state and what better way to signify this than by reimposing jizyah. He was aware such a step would please the ulema as well and the decision to staff the administration of the khazanah-ijizyah with members of this class was simply another step of appeasing the ulema. He hoped that the clerical class would help him in rallying Muslim popular support behind him.

Thus, what our discussion so far clearly establishes is that Aurangzeb was aware of the Mughal traditions of administration and governance that had been put in place by his predecessors and he was not keen on deviating from them. However, his religious rhetoric was often determined by political exigencies and by doing so he ended up giving a religious undertone to his politicking. His commitment to upholding Islamic principles was primarily a means to legitimize his precarious political position that had become evident post his actions of imprisoning his father and executing his brothers. It was as part of his efforts to reinforce that his kingship conformed to orthodox Islamic principles of statecraft that one finds him publicizing his acts of banning music, literature and other un-Islamic practices like celebration of nauroz, tuladan, jharokha darshan. However, this paper has already shed light on the limited nature of most of these prohibitions thereby demonstrating their inefficacy in the wider social arena. Even the policy of imposing jizyah which held within it the promise of reverting to a more orthodox setup was a step primarily taken to mobilize support in order to meet the political challenges that Aurangzeb faced. Interestingly, despite the imposition of jizyah, Aurangzeb did not bring about any radical change in the functioning of the state.

The ulema gained no considerable say in workings of the state and neither did Aurangzeb give up his policies of assimilating non-Muslims in his administration or providing financial support to non- Muslim religious institutions and individuals. There was no state sponsored drive to bring about mass conversions nor do we have any evidence pointing to a 'Hindu genocide'. All these indicate that Aurangzeb's religious rhetoric was more motivated by realpolitik than from a genuine need to exercise and implement the rules of the sharia in society. Nowhere does this become clearer than in Aurangzeb's policies of selective temple desecration.

\section{Aurangzeb and his Policies of 'Selective' Temple Desecration}

Historians of the likes of Jadunath Sarkar and S.R. Sharma have used the notion of temple desecration to vilify Aurangzeb. According to them, Aurangzeb's bigotry and anti-Hindu nature expressed itself in 'wanton acts of temple desecration'. They pointed out his destruction of the Keshavnath temple in Mathura, Vishwanath temple in Benares and the destruction of temples throughout Rajputana as evidences of such wanton acts. While none of these evidences are incorrect but what such arguments lack is a proper contextualization of these actions. Richard Eaton is his very influential article on 'temple desecration and IndoMuslim states' very rightly argued that the notion of temple desecration was a very politically motivated action in the context of pre-modern India, prevalent from even before the advent of Islam into India.

The political role played by temples in consolidating political authority is well known to most scholars of South Asian history. Royal temples housing the state deity often referred to as kuladavata expressed the sovereignty of the king thereby allowing such temples to serve as sites where kingship was created, legitimized and often revitalized. Given this political connection between temple, deity and kings scholars like Richard Davis and Richard Eaton have demonstrated numerous instances of temple desecration seen through early medieval Indian history occurring during times of inter-dynastic conflicts. In 642 A.D, the pallava king Narasimhavarman attacked the 
Chalukyas and destroyed their royal temple looting their state deity from their capital. Such actions of destroying royal temples and looting the central deity were carried out with the explicit aim of detaching a vanquished king from the most visible sign of his former legitimacy. Thus, the act of temple desecration was well established within the Indian political rhetoric. During the period of the Turkish conquest, they replicated these political patterns and traditions. Unfortunately, we have not been able to determine the exact number of temples destroyed by the Turkish forces as records left, if any have often not survived. Furthermore, the eagerness of court chroniclers to portray their patrons as ideal Muslim kings often resulted in actions of temple destruction being attributed to kings even where there were no such actions performed.

Based on epigraphic and literary evidences, Eaton identifies eighty instances of temples desecration spanning over five centuries (1192-1729), most of which were along a moving military frontier carried out by the state to denounce the legitimacy of vanquished local ruling houses. For instance, as the Mughal state annexed new territories, temple desecration accompanied these new conquests as is evident in Assam where the Mughal defeat of the Ahoms was followed by destruction of the chief temples patronized by the Ahom rulers. Such a theoretical understanding of temple desecration does not deny the destruction of temples but places it within a much larger tradition associated with political needs of states, rather than as an ideological weapon for suppressing the Hindus. From Akbar's period the Mughals saw temples as part of state property and took steps to protect them, renovate them and even patronize them. These policies continued with Aurangzeb who as has been documented earlier patronized temples and their functionaries. A farman from 1659 to officials in Banaras instructed them to protect Hindu temples and their functionaries and prevent any unlawful harassment of them so that they could continue praying for the continuation of the Empire. But then were there temples that Aurangzeb destroyed and if yes, why?

While it is true that Aurangzeb did destroy temples like the famed Vishwanath temple at Benares and the Keshavnath temple at Mathura, there was no instruction given regarding the general desecration of all temples throughout the empire. The temples that however still faced the wrath of the emperor suffered such a fate primarily because of the close linkages that existed between temples and temporal authority in pre-modern India. Following the treaty of Purandhar, Jai Singh the Rajput chieftain from Amer made great efforts to bring about an alliance between Aurangzeb and Shivaji. The subsequent visit of Shivaji to the emperor's court and the resultant conflict between which saw Shivaji imprisoned is by now a very popular tale that needs to recount. Shivaji's later escape from prison is an equally well-known incident. However, Aurangzeb suspected Jai Singh's complicity in Shivaji's escape. Subsequently, the Vishwanath temple built by Jai Singh was destroyed by Aurangzeb as a punishment for Jai Singh's alleged complicity in Shivaji's escape. The year 1670 witnessed a revolt among the Jats of Mathura. Once, Aurangzeb had captured and punished the ring leaders, he ordered the destruction of the Keshavnath Temple. Similarly, several temples throughout Marwar and Mewar were destroyed when Aurangzeb was suppressing the violent Rajput rebellion that had broken out in these two regions. Interestingly Aurangzeb was not the only Mughal Emperor to resort to such tactics. When Shahjahan was suppressing the Bundela rebellion, he destroyed the great temple at Orchha that was patronized by the rebel Jhujjar Singh Bundela. What these incidents demonstrate is that when non-Muslim subjects of the Mughal emperors engaged in open rebellion, the state resorted to principles of 'selective' temple desecration, targeting particularly those temples that were clearly associated with the rebel groups or individuals. Therefore, selective temple desecration appears to be a potent political action that Mughal emperors including Aurangzeb adopted to denounce the very legitimacy of those who posed a threat to the Mughal political order. The political nature of these acts of temple desecration becomes all the moreclear when we examine Aurangzeb's attitude in the Deccan. Having annexed Bijapur and Golconda in 1687, Aurangzeb's desire was to expand further south and bring under imperial control the vast country that extended upto Jinji. This region was populated with a number of Hindu chieftains and Zamindars. To appease these groups, one finds Aurangzeb never resorting to acts of temple desecration even when Hindu rajas of the region like Pam Nayak. The Nayaks of Madurai and Jinji opposed the Mughals. This indicates that temple desecration was a very political act, resorted to or desisted from as and when it suited the political requirements of Aurangzeb. To confuse this to be an expression of his faith would be a historical anachronism.

Thus, to conclude this paper attempts to examine the politics and piety of Aurangzeb. Though several of his actions including the imposition of jizyah, the desecration of temple, banning of music have all been interpreted as part of his attempts to organize a state based on Islamic tenets where a conscious policy was followed to alienate Hindus, this paper tries to show that it is important to contextualize such action before drawing inferences. This paper attempts to explore the politics that prompted actions like levying jizyah or following a policy of selective desecration of temples and it is argued that in most instances it was out of Aurangzeb's need to maintain his political authority or mobilize a certain section of the population that he resorted to such activities. Thus, while the paper does not deny the historical facts around the impostion of jizyah or the destruction of temples, it presses for a closer scrutiny of these actions to see whether indeed it was the piety of Aurangzeb that was manifesting itself through such acts or was it simply the realpolitik that motivated such actions.

\section{References}

1. Alamgir, Muihuddin (1974) Adab-i-Alamgiri (Vincent Flynn, Trans.). Phd. Dissertation, Australian National University, Australia.

2. Bernier, Francoise (1989) Travels in the Moghul Empire (I.Brock, Trans.). Low Price Publications, New Delhi, India. 
3. Khan, Saqi Mustaid (1947) Maasir-i-Alamgiri (Jadunath Sarkar, Trans.). Royal Asiatic Society of Bengal, Kolkata, India.

4. Manucci, Niccolao (1990) Storia Der Mogul (W.Irvine, Trans.). Low Price Publications, New Delhi, India.

5. Nagar Ishwardas (1978) Futuhat-i-Alamgiri (Tasneem Ahmed,Trans.). New Delhi: Idarah-i-Abadiyat-i-Dilli; Khan,Ali Muhamamad (1927). Mirat-i-Ahmadi (Saiyyad Nawab Ali and Charles Seddon, Trans.). Oriental Institute, Baroda, Gujarat, India.

6. Nimacha Hamiduddin Khan (1949) Ahkam-i-Alamgiri ( Jadunath Sarkar,Trans.). M.C.Sarkar and Sons, Kolkata, India.

7. Alam Muzaffar (2004) Languages of Political Islam in India. Permanent Black, New Delhi, India.

8. Ali Athar (1997) The Mughal Nobility under Aurangzeb. Oxford University Press, New Delhi, India.

9. Ali Athar (2006) Mughal India: Studies in Polity, Ideas, Society and Culture. OUP, New Delhi, India.

10. Brown, Katherine. (2007) Did Aurangzeb Ban Music: Questions for the Historiography of his Reign. Modern Asian Studies 41(1): 77-120.

11. Chandra Satish (1969) Jizyah and State in Seventeenth Century India Journal of the Social and Economic History of the Orient 12(3): 322 340.

12. Chandra, Satish (1986) Cultural and Political Role of Delhi: 1675:1725. In: Frykenberg RE (Eds.), Delhi Through the Ages: Essays in Urban History, Culture and Society. Oxford University Publications, New Delhi, India.

13. Chandra, Satish (2002) Parties and Politics at the Mughal Court. New Delhi: Oxford University Press.

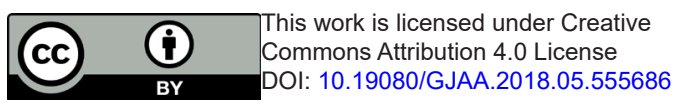

14. Chandra, Satish (2003) The Religious Policy of Aurangzeb. In Satish Chandra (Eds.), Essays in Medieval Indian History. Oxford University Publications, New Delhi, India.

15. Eaton, Richard (2000) Essays on Islam and Indian History. Oxford University Press, New Delhi, India.

16. Farukhi Z (1972) Aurangzeb and His Times. Idara-i-adbiyat-i-Delhi, New Delhi, India.

17. Faruqui Munis (2014) Dara Shukoh, Vedanta and Imperial Succession in Mughal India. In: Vasudha Dalmia and Munis Faruqui (Eds.), Religious Interactions in Mughal India. Oxford University Publications, New Delhi, India.

18. Nizami KA (1985) State and Culture in Medieval India. Adam Publishers, New Delhi, India.

19. Richards JF (1993). The Mughal Empire. Cambridge University Press, Cambridge, USA.

20. Sarkar, Jadunath (1928) History of Aurangzeb, 5 Vols. M.C.Sarkar and Sons, Kolkata, India.

21. Sharma SR (1940) The Religious Policy of the Mughal Emperors. Oxford University Press, New Delhi, India.

22. Trushke, Audrey (2017) Aurangzeb: The Man and the Myth. Penguin Books, Delhi, India.

23.Zayman, Taimiyya (2007) Inscribing Empire: Subjectivity and Sovereignty in Mughal Memoirs. Ph.D Dissertation, University of Michigan, USA.

\section{Your next submission with Juniper Publishers will reach you the below assets}

- Quality Editorial service

- Swift Peer Review

- Reprints availability

- E-prints Service

- Manuscript Podcast for convenient understanding

- Global attainment for your research

- Manuscript accessibility in different formats

( Pdf, E-pub, Full Text, Audio)

- Unceasing customer service

Track the below URL for one-step submission https://juniperpublishers.com/online-submission.php 